\title{
Accounting Conservatism and Performance of Nigerian Consumer Goods Firms': An Examination of the Role of Accruals
}

\author{
David Okelue Ugwunta ${ }^{1} \&$ Boniface Uche Ugwuanyi ${ }^{2}$ \\ ${ }^{1}$ Department of Insurance and Risk Management, Enugu State University of Science and Technology, Nigeria \\ ${ }^{2}$ Department of Accountancy, Enugu State University of Science and Technology, Nigeria \\ Correspondence: David Okelue Ugwunta, Ph.D., Department of Insurance and Risk Management, Enugu State \\ University of Science and Technology, Nigeria. E-mail: david.ugwunta@esut.edu.ng.
}

Received: September 15, 2018

doi:10.5430/ijfr.v10n1p1
Accepted: November 7, 2018

Online Published: November 18, 2018

URL: https://doi.org/10.5430/ijfr.v10n1p1

\begin{abstract}
In this study the evidence over the existence and magnitude of the assumed negative relation between accounting conservatism and firm performance in Nigeria was examined. Data from the annual financial statements of firms under the Consumer Goods sectoral classification on the Nigerian Stock exchange was used. The hypotheses were tested using the panel least squares while assuming the fixed effects. Opposed to the assumed negative relation, findings from the study suggest that accounting conservatism has a positive but non-significant effect on firm performance. This implies that firms in the Nigerian Consumer Goods sector do not practice accounting conservatism and hence produce low financial reporting quality. This is given the absence of accruals quality achieved when the reported information reported is credible and free of error and bias, intentional or otherwise. The study recommends that firms in Nigeria should be penalised if reported information are found to incomplete and opaque not free of error and bias.
\end{abstract}

Keywords: accounting, conservatism, performance, accruals

\section{Introduction}

The most important source of superficially reasonable information on companies is the financial statement. Inspite of the prevalent use and continuing improvement in financial statement, users are concerned that accounting practice(s) has failed to keep pace with swift economic and technological vagaries which habitually affect the worth significance of accounting information. Felix and Rebecca (2015) pointed out that the international accounting standard board framework for the preparation and presentation of financial statement notes that information is appropriate when it stimulates the economic verdicts. Accounting information must be accomplished of making a difference in a decision by assisting comsumers to forecast the outcomes of past, present, and future dealings.

Accounting conservatism has been one of the palpable features of financial recording which have been united by theory and practice of accounting for stretched time. According to Chen, Chen and Su (2001) conservatism has been measured as an unsettled and prevailing piece in accounting and financial recording (statements). The prominence of conservatism is that managers have substantial choice in gauging firms' financial proceedings, as tolerable within accounting guidelines. The notion of conservatism is that profit should not be expected, but should expect the acknowledgement of all losses (Watts, 2003). Therefore conservatism can deliver worth relevant information that has not yet been apprehended in bottomline numbers (Felix and Rebecca, 2015).

Accounting information principally renders services to groups and individuals who prefer to use qualitative and measurable information to acquire their investment goals. Making ideal decisions about investing in any business entity entails plain and comparable financial information. Consequently, preparing the information valuable in making investment decisions is one of the ultimate rudiments of making the investors interested in conducting economic processes. Financial reports are known as the major important source of financial information of firms. This is why the fundamentals of preparing financial statements are highly important. The underlying bases of preparing financial statements known as accounting standards should have formal characteristics and be consistent for financial statements and finally make the financial statements comparable. Therefore, the accounting philosophies and inclinations aim to balance the positiveness of the managers, safety of the stakeholders' welfares 
and reasonable presentation of the financial statements and use conservatism concept accordingly (Mohammad, Heyran, and Golestani, 2013).

Conservatism is one of the indispensable characteristics of financial reporting by which the quality of accounting and financial reporting has been at least improved from the start of the 20th century. Literature expansively examined whether conservatism is a suitable specification for the financial statement. Conservatism is a concept widely used by the accountants as an obliging principle of accounting. However, it has preserved the position among the other accounting principles irrespective of the recurrent critics considered. Conservatism has more certain effect on efficiency of the investment through the impacts on the financial decisions (Chen et al, 2009). Evidences suggest that there are conservative reporting in America, England and other European countries and most recently in developing countries such as Nigeria. Hence, the presentation, method and the way to compute the data are very significant in terms of qualitative aspect which the financial managers and analyzers regard. Using quantitative models to compute the level of conservatism, the measure is determined to quantify accounting information quality and investigate the interaction between the concept and firm performance. Consequently, this study seeks to find the effect of accounting conservatism using accruals on the performance of firms in the Nigerian breweries sub-sector of the Consumer Goods sector of the Nigerian Stock Exchange.

\section{Review of Related Literature}

\subsection{The Concept of Conservatism}

While there is a wide understanding upon the conservatism in preparing financial statements, there is no comprehensive definition of this concept. Givoly \& Hayn (2000) define conservatism as selecting an accounting approach under uncertainty condition which would finally lead to lower assets and revenues and has the least positive influence on the owners' equity. Gim and Zhank (2000) notes that conservatism includes isolating the whole impending losses and non-recognition of the promising earnings. Basu (1997) defines conservatism as a procedure whereby advanced degree of dependability is applied in recognizing and recording the earnings and hopeful news (incremental value); while lower degree of dependability is used in recognizing losses and detrimental news. Penman and Zhang (2000) perceived that accounting conservatism is comprised of selecting an appraised method of accounting which depicts clearly the book value of the assets at a lower level. This is a dominant typical of financial reporting which have been focussed on in the recent years because of the famed failures of firms such as Enron and WorldCom (Mohammed et al., 2013). Some other scholars like Watts (2003), Roychvrdary and Watts (2005) and LaFond and Watts (2006) however, distinguished two main realms of conservatism that have been reflective in literature: downward bias of book value of the equity to its market value; and the tendency to quick recognition of the costs and deferrals in recognizing revenue. The degree of accounting conservatism suggests a more timely incorporation of economic damages into accounting earnings than of economic increases (Ball, Robin and Wu, 2000).

Authors such as García-Lara, García Osma, and Penalva (2009) and Ahmed and Duellmand (2011) obtained empirical evidence of the positive association between accounting conservatism and forthcoming profitability because of enhancements in good organizations of investment. Same as financial reporting quality, accounting conservatism has become an inducement to managers to sponsor better accomplishing projects that increase future performance since these economic or financial projects are more profitable (Martínez-Ferrero, 2014). Meanwhile, Ahmed and Duellmand (2011) show that conservative firms relish better future profitability arising from investment in more efficient projects. Bushman and Smith (2001) report that firms with higher financial reporting quality are certain to encourage profitable investment decisions and thus could view increases in their corporate performance. According to Martínez-Ferrero (2014) conservative accounting echoes bad news for the company speedily than good news. This is because this tactic inclines to decrease risks of lawsuits.

\subsubsection{Measures of Conservatism}

The most popular measures of conservatism include net assets, earnings and accruals measure, and earnings-return relationship measure (Mohammed, et al., 2013).

Net Assets Measure: The market value of assets and liabilities comprises the net disparities in the assets of each period. However, all these disparities are not chronicled in the accounts and are not replicated on financial reports. According to the conservatism concepts, increasing assets' value (earnings) which is not adequately provable will not be documented; while their decreasing value with alike provability will be reduced. Feltham and Ohlson (1995) model is typically used to evaluate the assets at a level lesser than the real assets. This models comprise those considerations with low splendour of operating assets based on the supposition that the accounting devaluation is 
bigger than the economic depreciation. Bior and Rayan (2000) in Mohammed et. al. (2013) used the ratio of book value to the market value. Taking other elements constant, using conservative accounting leads to reporting lesser net assets and lesser ratio of book value to market value (Watts, 2003).

Earnings Measure and Accruals (Earnings to Accruals Ratio): Conservatism documents that the earnings are more tenacious than the losses because the invulnerability upsurges in the value of the assets (earnings) which are not recognized when they occur. However, these upsurges will be understood during the upcoming periods by generating cash flows. The losses are not typically repeatable in future periods and they have less persistency than the earnings. Unpredictability of losses and persistency of the earnings and their disparities provide a gauge of conservatism. This irregularity behavior of conservatism with the profits and losses will lead to irregularity in realizing accruals. As Givoly \& Hayn (2000) articulate that conservatism causes the retained earnings to decay over time. Givoly \& Hayn (2000) believe that the indication and the level of retained accruals over the time are some methods of conservatism. Taking other factors constant, clear constancy of the negative accruals (such as reserves) among the firms during a long period is an indicator of conservatism and the build-up rate of negative accruals designates the level of changes at the conservatism level during the time (Givoly \& Hayn , 2000).

Earnings-Stock Return Measure: Stocks market worth inclines to show the fluctuations in the assets value at the time of manifestation; these fluctuations might be in form of diminution of assets' value or upsurges in their value. As a significance, it can be concluded that the stock return has a predisposition to be timely and hence, conservatism primes accounting losses to be realized more timely than earnings. Accordingly, it is foretold that losses are more dependable with the stock returns than incomes. Basu (1997) explained that stock return and accounting income incline to show losses of a same period, but the stock returns reflect the losses earlier than accounting income (Watts, 2003). Basu (1997) used stock return to measure the news between earnings and stock return and found that the response of earnings to the bad news (negative stock return) is timelier than the response of earnings to the good news (positive stock return). Basu (1997) also showed that the persistency of the negative changes in the earnings is less persistent than their positive changes. Basu (1997) provided a measure to evaluate the conservatism in which there was a profit or loss viewpoint and is called timely asymmetry.

\subsection{Theoretical Framework}

The theoretical framework for this study is based on the agency theory. The depature of ownership from management in modern corporations provides the perspective for the function of agency theory. Corporations have widely disseminated ownership that are not ordinarily involved in the day-to-day running of the affairs of the firm. In this case, an agent is appointed to manage the regular operations of the company. The dissemination between ownership and control generates the probability for clashes of interest between agents and principals, which result in costs. One of the significant faces of business in the 1990s was the adoption of the Agency theory to discourse the managerial dissipations of the 1970s and 1980s (Simerly and Mingfaing, 2000). The classical Agency thought was developed by Berle and Means (1932) who detected that ownership and control which have been disconnected in larger corporations because of thinning in equity positions provided an opportunity for professional managers to act in their own best interest. Despite the earlier works of Berle and Means (1932), Jensen and Meckling (1976) and Grossman and Hart (1982) are forerunner in Agency theory research.

Since the formative paper of Jensen and Meckling, huge literatures on the Agency theory explanations have been advanced (Harris and Raviv, 1991). As stated by Simerly and Mingfang (2000) abundance of the actions of management are related with increasing the size of the organizations and management were motivated not by a longing for capitalize on shareholders' wealth but by breaks for the self-glorification. Therefore, the Agency theory is a predetermined device suggested to balance the objects of management and that of shareholders. Sultz (1990) and Harris and Raviv (1990) provides further advance to the agency model. However, a new style to challenging the agency theory was propelled by Allen and Wharton (2002) who pushed that agency costs represent important snags in corporate governance for corporatized entities. Under the agency cost hypothesis, high leverage or a low equity/asset ratio lessens the agency cost of outside equity and rises firm value by pressuring or expansion managers to act more in the interest of shareholders (Allen and Wharton, 2002). For Dybrig and Douglas (1984) Agency cost theory is presented in the form of models in which managers have improved information than investors but managers' compensation schemes are finetuned to assure optimum capital investment.

The most important basis of agency theory is that the managers are usually motivated by their own personal improvements rather than considering shareholders' interests and maximizing shareholder value (Atu, Atu, Enegbe and Atu, 2016). Consequently, management has an enticement to discretionary apply conservatism in the company's financial report procedure either to shod up or weaken earnings. Mos particularly to receive any bonuses that may be 
tied to the company's earnings (performance-related pay). This constructs an information asymmetry in that managers can exercise the discretion they have on accruals, which in turn reduces the relevance and reliability of reported earnings, and the whole financial statement. Thus, economic theory proposes that voluntary disclosures and amplified information quality condense information asymmetries between producers and consumers of financial statement information.

\subsection{Empirical Review}

Table 1. Relevance of degree of accounting conservatism on financial performance

\begin{tabular}{|c|c|}
\hline Author(S) & Objective \\
\hline Kythreotis (2014) & $\begin{array}{l}\text { examined the extent to } \\
\text { which the objective of } \\
\text { IASB to create higher } \\
\text { quality financial } \\
\text { statements has been } \\
\text { achieved in light of the } \\
\text { conceptual framework. }\end{array}$ \\
\hline $\begin{array}{l}\text { Kordlouie, } \\
\text { Mohammadi, } \\
\text { Naghshineh } \\
\text { Tozandejani } \\
\text { (2014) }\end{array}$ & $\begin{array}{l}\text { investigated the } \\
\text { relationship between } \\
\text { accounting } \\
\text { conservatism and the } \\
\text { quality of financial } \\
\text { statements of the } \\
\text { companies accepted in } \\
\text { Tehran Stock Exchange } \\
\text { (TSE) market. }\end{array}$ \\
\hline Ramadan (2015) & $\begin{array}{l}\text { to identify the factors } \\
\text { that affect the earnings } \\
\text { quality } \\
\text { Manufacturing } \\
\text { Companies listed at } \\
\text { Amman Stock } \\
\text { Exchange (ASE) }\end{array}$ \\
\hline
\end{tabular}

The degree of relevance and reliability was measured by the usage of four alternative regression models in a a sample of of listed companies of fifteen European countries that have adopted IFRS mandatorily.

regression analysis

four variables selected, namely: financial leverage, firms performance, investment decisions and accounting conservation, in presence of two control variables, namely: firms size and cash holding. Ordinary least square (OLS) cross sectional regression model was applied on a sample of (58) manufacturing companies

Geimechi And examines the factors panel regression Khodabakhshi (2015

Gharibi And
Nemati (2015)

Park And Chen (2006) that affect the level of accounting

conservatism in those companies with regard to company size, disclosure, financial leverage, discretionary accruals.

studied the relationship between accounting conservatism, financial crisis and stock price crash risk

investigated

how accounting conservatism affects the a regression model using information derived from financial statements of 93 companies listed in Tehran Stock Exchange since 2007 to 2014

Used the perspective of the Feltham and Ohlson 1995's valuation model to conducts its

\section{Findings}

Generally, the findings that are obtained support an increase in relevance, while the reliability seems to be unchanged.

a significantly positive relationship between accounting conservatism and the quality of financial reports

The results of the analysis showed the existence of statistically significant direct impact for each of firm performance, financial leverage and accounting conservation on earnings quality.

The findings indicate that firm size and discretionary accruals conservatism influence disclosures.

the relationship between accounting conservatism and financial crises is negative, and that financial crises will decrease by using accounting conservatism. There is also the same negative relationship between accounting conservatism and stock price crash risk that suggests that firms in different life-cycle stages have different financial characteristics that 
value-relevance of accounting information under different economic attributes

$\begin{array}{lr}\text { Aloke } & \text { Ghosh, } \\ \text { Zhaoyang } & \text { And } \\ \text { Prem (2009) } & \end{array}$

Lee And Powel (2010)

Louis, Sun And Urcan (2011)

Saghafi Sadidi (2008)

And

investigated earning quality and earning response coefficient when stable increase of earning was accompanied by stable increase of income.

investigated effect of Regression analysis conservative procedures in financial reporting on companies' financial flexibility.

studied the relationship between accounting conservatism and held cash value and abnormal short-term return of the company

effect of conservatism on earning quality and return on shares and the relationship between conservatism and earning quality and return rate.

Abedini, Ranjbar
And Mozaffari
(2014)

Mohammad, Heyrani Golestani (2013)

And studied the effect of accounting

conservatism and earning quality on reaction of investors to cash holding level in the companies listed on Tehran Stock Exchange.

investigated the impact of conservatism on the quality of the accounting information and decisions of the shareholders and the Tehran listed firms

Source: Authors' Compilation, 2018 hypothesis tests using comprehensive proxies such as conservatism estimates from the valuation model and corporate life-cycle stages

Regression analysis

Regression analysis

Regression analysis

Correlation analysis

Regression analysis

cross-sectional correlations and linear regression affect the value-relevance of the accounting information

showed that companies with earning growth along with income growth had higher earning quality than those with growth along with cost decrease. Also, companies with increased income had higher operating future performance

showed that companies with higher conservative degree had less financial flexibility in their liquidity management, financing decisions, sensitivity of investment to financial limitations and payment policies for shareholders

concluded that accounting conservatism had a positive effect on the relationship between the company's held cash fund and future operating performance

indicated that the earning quality index introduced based on conservatism could be stated as a part of the difference between return rate of operating assets and return rate of shares in the current and next years indicated that financial reporting environment and change in quality of the published information had no effect on the shareholders' reaction to cash balance

reveal that there is a relationship between conservatism and information quality. It is also documented that conservatism positively influences on each characteristic of relevancy, reliability and timeliness

In theory, accounting conservatism causes a decline in value relevance of financial statements and this study aimed to find evidence on existence and magnitude of the assumed negative relation on firm performance. In order to validate the research, the study examined the relation between accounting conservatism and firm performance using three conservatism measures of total accruals, discretionary accruals and non-discretionary accruals using empirical evidence to test a relevant hypothesis. 


\section{Methodology}

The research design adopted for this study is the ex-post facto while the Panel Least Squares (PLS) was applied to annual data assembled from the annual reports and accounts of the sampled Nigerian firms. The general model was specified thus:

$$
\mathrm{NPM}_{\mathrm{it}}=\mathrm{a}+{ }_{\mathrm{b} 1} \mathrm{ACC}_{\mathrm{it}}+{ }_{\mathrm{b} 2} \mathrm{OACC}_{\mathrm{it}}+{ }_{\mathrm{b} 1} \mathrm{NOACC}_{\mathrm{it}}+\mathrm{U}_{\mathrm{it}}
$$

Where:

$\mathrm{a}=$ constant;

ACC $=$ Total Accruals for firm $\mathrm{i}$ at time $\mathrm{t}$.

$\mathrm{NPM}=$ Net Profit Margin for firm $\mathrm{i}$ at time $\mathrm{t}$

$\mathrm{OACC}=$ Operating Accruals for firm i at time $\mathrm{t}$.

NOACC $=$ Non-Operating Accruals for firm $i$ at time $t$.

\subsection{Definition of Variables}

Conservatism is the independent variable of this study which Basu (1997) defined as the higher degree of dependability for identifying and recording wanted news (incremental value); and using lower degree of dependability for identifying and recording unwanted news (declining value). Givoly \& Hayn model has been applied to measure the conservatism. Givoly and Hayn (2000) used discretionary accruals to measure conservatism. In line with Givoly and Hayn (2000) total and discretionary accruals are computed by the following models:

$$
\begin{aligned}
& \text { ACCit }=(\text { Nlit }+ \text { DEPit })-\text { CFOit } \\
& \text { OACCit }=\Delta(\text { ARit }+ \text { Iit }+ \text { PEit })-\Delta(\text { APit }+ \text { TPit }) \\
& \text { NOACCit }=\text { ACCit }- \text { OACCit }
\end{aligned}
$$

Where:

ACC is the total accruals,

NI is the net income before extraordinary items,

DEP is the depreciation and

$\mathrm{CFO}$ is the operating cash flows.

OACC is the operating accruals (nondiscretionary),

$\mathrm{AR}$ is the accounts receivable,

I is inventory,

$\mathrm{PE}$ is the prepaid expenses,

AP id the accounts payable and

TP is the taxes payable.

Finally, NOACC which indicates the non-operating accruals (discretionary).

Dependent variable: Net profit margin = NPM/ Turnover

\section{Findings}

The panel least squares (PLS) was applied to a series of data gathered from the annual reports and accounts of the sampled firms in Nigeria the results presented in Table 2. 
Table 2. Regression results

\begin{tabular}{|c|c|c|c|}
\hline \multicolumn{4}{|c|}{ Dependent Variable: NPM } \\
\hline \multicolumn{4}{|c|}{ Method: Panel Least Squares } \\
\hline \multicolumn{4}{|c|}{ Date: $12 / 19 / 17$ Time: $10: 45$} \\
\hline \multicolumn{4}{|c|}{ Sample: 20052016} \\
\hline \multicolumn{4}{|l|}{ Periods included: 12} \\
\hline \multicolumn{4}{|c|}{ Cross-sections included: 2} \\
\hline \multicolumn{4}{|c|}{ Total panel (balanced) observations: 24} \\
\hline \multicolumn{4}{|c|}{ White diagonal standard errors \& covariance (d.f. corrected) } \\
\hline Variable & Coefficient & Std. Error & Prob. \\
\hline$\overline{\mathrm{ACC}}$ & 0.000642 & 0.000530 & 0.2532 \\
\hline$\overline{\mathrm{OACC}}$ & 0.023723 & 1.160244 & 0.2758 \\
\hline$\overline{\mathrm{NOACC}}$ & 0.000764 & 0.409052 & 0.6921 \\
\hline \multirow[t]{2}{*}{$\overline{\mathrm{C}}$} & 0.187806 & 0.061932 & 0.0126 \\
\hline & Effects Spec & ification & \\
\hline \multicolumn{4}{|c|}{ Cross-section fixed (dummy variables) } \\
\hline \multicolumn{4}{|c|}{ Period fixed (dummy variables) } \\
\hline R-squared & 0.575903 & Mean dependent var & 0.194768 \\
\hline Adjusted R-squared & 0.024577 & S.D. dependent var & 0.305878 \\
\hline S.E. of regression & 0.302096 & Akaike info criterion & 0.735054 \\
\hline Sum squared resid & 0.912620 & Schwarz criterion & 1.422252 \\
\hline Log likelihood & 5.179353 & Hannan-Quinn criter. & 0.917368 \\
\hline F-statistic & 3.044578 & Durbin-Watson stat & 2.565882 \\
\hline$\overline{\text { Prob(F-statistic) }}$ & 0.041855 & & \\
\hline
\end{tabular}

Source: Author's E-view 9.0 Output, 2017

Results from the above panel least squares shows that total accruals (ACC), operating accruals (nondiscretionary) and non-operating accruals (discretionary) have positive but non-significant effect on firm performance in Nigeria. This implies that firms in the Nigerian Consumer Goods sector failed to present proof on presence and scale of the assumed negative relation between accruals and firm performance. Thus, there is lack of accrual quality which is achieved when the information reported to investors and to the market is credible and free of error and bias, intentional or otherwise, thus expanding the scope and quality of reported information and ensuring that market participants are fully informed.

\section{Conclusion and Recommendations}

The accounting system which is not proficient of providing the required managerial information with a proper quality is not considered as an efficient investment decicion making instrument. The findings of this study seems to be in agreement with reports of García-Lara, García Osma, and Penalva (2009) and Ahmed and Duellmand (2011) who obtained empirical evidence of the positive association between accounting conservatism and forthcoming profitability attributed to enhancements in good organizations of investment. Martínez-Ferrero (2014) proposes that accounting conservatism has become an inducement to managers to sponsor better accomplishing projects that increase future performance since these economic or financial projects are more profitable. Also, Ahmed and Duellmand (2011) show that conservative firms relish better future profitability arising from investment in more efficient projects. Thus, it seems that the postive relation suggested from the findings could be ascribed to enhancements resulting in good positioning of investments thereby, becoming an inducement to managers to undertake better promising investments that increase future performance. The study thus recommends that firms in 
Nigeria be required to prepare and present their financial statements in a complete transparent manner free of error and bias and that any firm found violating transparency of accounting information to be heavily penalised by the relevant authorities. Also, since non-operating accruals are discretionary, firms found to manipulate discretionary non-operating accruals in a way to interfere with the true and fair view of firm performances and mislead users should be heavily penalised.

\section{References}

Abedini, B., Ranjbar, M. H., \& Mozaffari, A. (2014). Investigating effect of accounting conservatism and earning quality on reaction of investors to cash stocks of companies accepted in Tehran Stock Exchange. International Journal of Academic Research in Accounting, Finance and Management Sciences, 4(1), 331-339. https://doi.org/10.6007/IJARAFMS/v4-i1/656

Ahmed, A. S., \& Duellman, S. (2011). Evidence on the role of accounting conservatism in monitoring managers' investment decisions. Accounting and Finance, 51(3), 6090-633. https://doi.org/10.1111/j.1467-629X.2010.00369.x

Allen, N. B., \& Wharton, B. P. (2002). Capital structure and firm performance, a new approach to testing agency theory and an application to the banking industry. Wharton Financial Institution Centre Publication.

Aloke, G., Zhaoyang, G., \& Prem, C. J. (2009). Sustained earnings and revenue growth, earning quality, and earning response. Coefficient SSRN Website.

Atu, O. O. K., Atu, F. O., Enegbe, O. P., \& Atu, E. C. (2016, February). Determinants of earnings management in Nigerian quoted companies. Igbinedion University Journal of Accounting, 1, 118-133.

Ball, R., Robin, A., \& Wu, J. (2000). Incentives versus standards: properties of accounting income in Four East Asian Countries. Journal of Accounting and Economics, 36, 253-270.

Basu, S. (1997). The conservatism principle and the asymmetric timeliness of earnings. Journal of Accounting and Economics, 24, 3-37. https://doi.org/10.1016/S0165-4101(97)00014-1

Bushman, R. M., \& Smith, A. J. (2001). Financial accounting information and corporate governance. Journal of Accounting and Economics, 32, 237-333. https://doi.org/10.1016/S0165-4101(01)00027-1

Chen, C. J. P., Chen, S., \& Su, X. (2001). Accounting information value relevance in the emerging chinese stock market. Journal of International Accounting Auditing and Taxation, 10, 1-22. https://doi.org/10.1016/S1061-9518(01)00033-7

Dybrig, P., \& Douglas, D. (1984). Bank fund, deposit insurance and liquidity. Journal of Political Economy, 91(1), 520-540.

Feltham, G., \& Ohlson, J. (1995). Valuation and clean surplus accounting for operating and financial activities. $\begin{array}{lllll}\text { Contemporary Accounting } & \text { Research, } & 11(2), & \text { Spring, } & \text { 689-709. }\end{array}$ https://doi.org/10.1111/j.1911-3846.1995.tb00462.x

García Lara, J., García Osma, B., \& Penalva, F. (2009). Accounting conservatism and corporate governance. Review of Accounting Studies, 14(1), 161-201. https://doi.org/10.1007/s11142-007-9060-1

Geimechi, G., \& Khodabakhshi, N. (2015). Factors affecting the level of accounting conservatism in the financial statements of the listed companies in Tehran stock exchange. International Journal of Accounting Research, 2(4), 41-46.

Gharibi, M., \& Nemati, K. (2015). Accounting conservatism, financial crises and stock price crash risk. Research Journal of Fisheries and Hydrobiology, 10(10), 790-796.

Givoly, D., \& Hayn, C. (2000). The changing time-series properties of earnings, cash flows and accruals: Has financial reporting become more conservative?. Journal of Accounting \& Economics, 29(3), 287-307. https://doi.org/10.1016/S0165-4101(00)00024-0

Harris, M., \& Raviv, A. (1991). The theory of financial structure. Journal of Finance, 46(1), 58-70. https://doi.org/10.1111/j.1540-6261.1991.tb03753.x

Kordlouie, H., Mohammadi, F., Naghshineh, N., \& Tozandejani, M. (2014). Role of accounting conservatism on the quality of financial statements. International Journal of Business and Management, 9(1), 129-139.

Kythreotis, A. (2014). Measurement of financial reporting quality based on IFRS conceptual framework's fundamental qualitative characteristics. European Journal of Accounting, Finance and Business, 3(2), 4-29. 
LaFond, R., \& Watts, R. (2008, March). The information role of conservatism. The Accounting Review, 83(2), 447-467. https://doi.org/10.2308/accr.2008.83.2.447

Lee, A., \& Powell, R. (2010). Excess cash holdings and shareholder value. University of New South Wales, Australia. https://doi.org/10.2139/ssrn.1585623

Louis, H., Sun, A., \& Urcan, O. (2011). Value of cash holdings and accounting conservatism. Smeal College of Business, Pennsylvania State University, University Park, PA, 16802. https://doi.org/10.2139/ssrn.1415562

Martínez-Ferrero, J. (2014). Consequences of financial reporting quality on corporate performance. Evidence at the international level. Estudios de Economía, 41(1), 49-88. https://doi.org/10.4067/S0718-52862014000100002

Mohammad, M. H. K., Heyrani, F., \& Golestani, N. (2013). Impact of conservatism on the accounting information quality and decision making of the shareholders and the firms listed on the Tehran Stock Exchange. International Journal of Academic Research in Accounting, Finance and Management Sciences, 3(3), 186-19. https://doi.org/10.6007/IJARAFMS/v3-i3/129

Park, Y., \& Chen, K. H. (2006). The effect of accounting conservatism and life-cycle stages on firm valuation. Journal of Applied Business Research, 22(3), 75-92.

Penman, S. H., \& Zhang, X. (2000). Accounting conservatism, the quality of earnings, and stock returns. The Accounting Review, 77, 237-264. https://doi.org/10.2308/accr.2002.77.2.237

Ramadan, I. Z. (2015). Earnings quality determinants of the Jordanian manufacturing listed companies. International Journal of Economics and Finance, 7(5), 140-146. https://doi.org/10.5539/ijef.v7n5p140

Roychowdhury, S., \& Watts, R. (2005). Asymmetric timeliness of earnings, marketto book and conservatism in financial reporting. Journal of Accounting and Economics, 44(1), 2-32.

Saghafi, A., \& Ghomareza, K. (2004). Studying and explaining relationship between earning quality and market reaction to cash earning changes. Accounting and Auditing Review, 37, 56-70.

Simerly, R., \& Mingfang, L. (2000). Environmental dynamism, capital structure and performance, a theoretical integration and an empirical test. Strategic Management Journal, 21(4), 450-465. https://doi.org/10.1002/(SICI)1097-0266(200001)21:1<31::AID-SMJ76>3.0.CO;2-T

Stulz, R. M. (1990). Managerial discretion and optimal financing policies. Journal of Financial Economics, 14(3), 251-270. https://doi.org/10.1016/0304-405X(90)90011-N

Watts, R. L. (2003). Conservatism in accounting part 1: explantions and implications. Accounting Horizons, 17(3), 207-221. https://doi.org/10.2308/acch.2003.17.3.207 